\title{
PROTEOLYTIC ENZYME SYSTEMS IN DEVELOPING RAT TISSUES
}

\author{
GARLTON E. BLACKWOOD, YVONNE HOSANNAH AND \\ INES MANDL
}
Department of Obstetrics and Gynecology, Columbia University, College of Physicians and Surgeons, New York

(Received 8th September 1967)

\begin{abstract}
Summary. The developmental progression of two endopeptidases, four exopeptidases, trypsin inhibitors and chymotrypsin inhibitors in rat embryos from fertilization to the fully formed foetus and beyond has been evaluated. Biochemical and histochemical procedures using the same chromogenic substrates were applied to study uteri at various stages of gestation, embryos from the 11th day of gestation to term, and kidney, liver and spleen from the 18th day of gestation to the adult stage. Activities were found to be lower in isolated embryos than in pregnant uteri but rates of increase were comparable except in the case of cystinedi- $\beta$-naphthylamidase which showed a greater rate of increase in uteri. Enzyme activities in liver, kidney and spleen were relatively high during the late stages of gestation, decreased at birth and increased again in postnatal tissues. The rate of change as well as the absolute values differed for each enzyme as well as for each tissue. There is evidence that soluble enzymes assayed by biochemical techniques are synthesized before particle-bound enzymes measured by histochemical techniques. Electrophoretic mobility, metal ion requirements and enzyme localization indicate that several closely related but distinct enzymes take part in foetal development.
\end{abstract}

\section{INTRODUCTION}

Evolutionary changes in proteolytic enzymes and their naturally occurring inhibitors form an integral part of foetal development. Proteolytic enzymes are almost certainly involved in the death of cells and the accompanying breakdown of large protein molecules to amino acids, a characteristic feature of embryonic growth and differentiation. Excessive cellular death during embryogenesis has been explained by Saunders (1966) as a method of eliminating organs and tissues that are useful only during embryonic and larval life or that are but phylogenic vestiges. The cellular death has been shown to be hormone controlled (Weiss \& Rossetti, 1951; Weber, 1962; Schneiderman \& Gilbert, 1964). For the most part injury and death of cells would release cellular components ranging from low molecular weight building blocks to macromolecules. The 
former contribute to pools of metabolites, enzymes and other compounds, while the macromolecules become incorporated into the machinery of other cells or are broken down to diffusible molecules and then added to an amino acid pool.

One aspect of development is the continuous breakdown of reserve protein into materials that can then be incorporated into a variety of new proteins. Deuchar (1960) found that cathepsins play an important part in somite development in the chick to provide amino acids which act as inducers of their own activating enzymes and thus control the rate of protein synthesis as well as the type of protein synthesized, depending on the amino acids present in the pool.

Under different experimental conditions several investigators (Mayersbach, 1958; Josefsson \& Lindberg, 1965; Lindberg, 1966) have shown increases in proteolytic activity as tissues developed. Lieberman (1966) found that plasminogen and trypsinogen activators were present in foetal pancreas but appeared at a relatively late stage in foetal development. Lindberg (1966) studied dipeptidase activity in the developing gastro-intestinal tract of pig, rat and man and found similarities between dipeptidases in these species. In the case of the human foetus he showed that the enzymes were fully developed at 11 weeks of gestation. More recently the same group (Lindberg \& Owman, 1966), studying five dipeptidases in the developing intestines of the rat, found low enzyme activities in the early stages of mucosal cell proliferation but significant increases at the onset of cell differentiation.

Specific natural inhibitors form an essential part of the proteolytic enzyme system and catheptic inhibitors have been found in both human and animal tissues (Blackwood, Mateyko \& Mandl, 1962; Blackwood \& Mandl, 1964; Blackwood, Mandl \& Long, 1965b). This may be one of the reasons why, in spite of increases in enzyme activity during embryogenesis, development proceeds without uncontrolled breakdown of proteins.

The study reported here seeks to follow the developmental progression of proteolytic enzyme systems in rat embryos from fertilization to the fully formed individual and beyond to the adult.

\section{MATERIALS AND METHODS}

The animals used in these experiments were Sprague-Dawley rats. Females, weighing 150 to $200 \mathrm{~g}$, were left with males overnight. When vaginal plugs were not present smears from the vagina were analysed; if plugs were present or spermatozoa were found in the vaginal smear, the animal was considered inseminated and this stage was designated as Day 1 of the gestation period. The length of the gestation in these rats is 21 to 22 days. At the appropriate stage, the uterus and foetuses were removed from the mother, representative portions of tissue were dissected out, pooled where necessary, weighed, placed in a test tube, quenched in dry ice and acetone mixture, then stored immediately at $-20^{\circ} \mathrm{C}$ until time for processing. Foetuses, after the 17th day of gestation, were killed by decapitation and their liver, kidneys and spleen excised, washed and stored for histochemical and biochemical evaluation. 
Throughout these studies proteolytic enzyme systems were investigated both biochemically and histochemically using chromogenic substrates of different specificities. For cathepsin B and trypsin-like activity benzoyl arginine- $\beta$ naphthylamide (BA-NA) was the substrate used, while for cathepsin $G$ and chymotrypsin-like activity glutaryl phenylalanine- $\beta$-naphthylamide (GP-NA) was used. The exopeptidase substrates used were leucine- $\beta$-naphthylamide (L-NA), glutamyl- $\beta$-naphthylamide (G-NA), arginine- $\beta$-naphthylamide (A-NA) and cystine-di- $\beta$-naphthylamide (Cy-NA). All biochemical assays were performed by a modified Bratton \& Marshall (1939) colorimetric reaction, the Goldbarg and Rutenburg procedure (Goldbarg, Pineda \& Rutenburg, 1959) for leucine naphthylamidase and other exopeptidases, and analogous methods worked out by Blackwood and Mandl (Blackwood \& Mandl, 1961 ; Blackwood, Erlanger \& Mandl, 1965a) for the endopeptidases. For biochemical studies tissues were transferred to glass homogenizing tubes immersed in crushed ice. Homogenization was effected in cold water $(100 \mathrm{mg}$ wet tissue/ml) in a glass homogenizer for $2 \mathrm{~min}$. The homogenate was then centrifuged for $10 \mathrm{~min}$ at $500 \mathrm{~g}$. The nitrogen content of each tissue homogenate was established by micro-Kjeldahl determinations (Markham, 1942).

Inhibition of trypsin and chymotrypsin activities by tissue homogenates was determined with BA-NA and GP-NA substrates as described by Blackwood \& Mandl (1961) and Blackwood et al. (1965a). Corrections were made for digestion of the substrates by catheptic activities of the tissue homogenates which are generally low at the $\mathrm{pH}$ used (Blackwood et al., 1965b) and for the partial destruction of these catheptic activities by tryptic and chymotryptic action.

Colorimetric readings in a B \& L Spectronic 20 colorimeter were expressed as $0.01 \mathrm{mg}$ homogenate nitrogen for L-NA-ase, $0.05 \mathrm{mg}$ homogenate nitrogen for A-NA-ase, $0.2 \mathrm{mg}$ homogenate nitrogen for G-NA-ase, $0.5 \mathrm{mg}$ homogenate nitrogen for Cy-NA-ase and $1.0 \mathrm{mg}$ homogenate nitrogen for BA-NA-ase and GP-NA-ase. Results are given in colorimetric readings to facilitate comparison and show relative values. The tabulated optical density values $\times 10^{3}$ can be converted readily to units based on micrograms of naphthylamine released from a standard colorimetric curve (Goldbarg et al., 1959). Expressed as theoretical readings per milligram homogenate nitrogen the activity units shown are, respectively, $1 / 100,1 / 20,1 / 5,1 / 2$ the values for $\mathrm{L}$-NA-ase, A-NA-ase, G-NA-ase and Cy-NA-ase, and as shown for BA-NA-ase and GP-NA-ase.

The histochemical methods applied are modifications of a method described by Glenner (1962) and followed by Long \& Hosannah (1966) for leucine naphthylamidase assay. The substrates were identical with those used for exopeptidase assay in the biochemical tests. Cryostat-cut sections were mounted on glass slides and after passage through a series of lipid solvents incubated in the appropriate substrate solution and diazonium salt. Appearance of red reaction products denoted the sites of enzyme activity.

Fractionation of the homogenate was performed at 20,000 and $90,000 \mathrm{~g}$, respectively, in a Spinco L-2 ultracentrifuge using a No. 50 rotor (Anderson, 1955). Electrophoretic analysis was done on $5.5 \%$ acrylamide gel in the vertical preparative gel electrophoresis apparatus of Raymond (1962) at 200 volts. After $1 \frac{1}{2} \mathrm{hr}$, the gel strips were removed, one strip stained with Amidoschwarz 
for proteins and identical strips immersed in the various substrate solutions and Fast Garnet GBC to visualize the migration of each enzymatic component.

\section{RESULTS}

Results reported encompass the developmental progression of proteolytic enzyme activities determined in homogenates of whole uteri throughout embryonic development, embryos from Day 11 to term as well as foetal and postnatal liver, kidney and spleen and corresponding histochemical studies on cryostatcut sections of these tumours.

In Table 1 biochemical data for enzymatic and inhibitor activities of uteri are summarized. Each value represents mean results from ten different littermates. BA-NA-ase activity was higher in pregnant than non-pregnant uteri. The difference in BA-NA-ase in the non-pregnant uterus and uteri to the 3rd day of gestation was infinitesimal. Between Days 3 and 5, however, activity increased over $60 \%(P>0.025)$, from the 5 th to the 8 th day the activity doubled $(P<$

TABLE 1

BIOCHEMICAL DATA OF PROTEOLYTIC ENZYME SYSTEMS IN NON-PREGNANT AND PREGNANT RAT UTERI AT VARIOUS STAGES OF GESTATION

\begin{tabular}{|c|c|c|c|c|c|c|c|c|}
\hline \multirow{3}{*}{ Uterus } & \multicolumn{8}{|c|}{ Substrate } \\
\hline & \multicolumn{2}{|c|}{$B A-\mathcal{N} A$} & \multicolumn{2}{|c|}{$G P-\mathcal{N} A$} & \multirow{2}{*}{$\frac{L-\mathcal{N} A}{E}$} & \multirow{2}{*}{$\frac{A-\mathcal{N} A}{E}$} & \multirow{2}{*}{$\frac{G-\mathcal{N A}}{E}$} & \multirow{2}{*}{$\frac{C y-\mathcal{N} A}{E}$} \\
\hline & $E$ & $\% I_{t}$ & $E$ & $\% I_{c}$ & & & & \\
\hline $\begin{array}{l}\mathrm{N} \\
\mathrm{P}_{3} \\
\mathrm{P}_{5} \\
\mathrm{P}_{8} \\
\mathrm{P}_{11} \\
\mathrm{P}_{18} \\
\mathbf{P}_{20}\end{array}$ & $\begin{array}{l}110 \\
115 \\
180 \\
390 \\
740 \\
732 \\
846\end{array}$ & $\begin{array}{l}42 \\
44 \\
25 \\
54 \\
68 \\
82 \\
83\end{array}$ & $\begin{array}{r}38 \\
37 \\
48 \\
69 \\
112 \\
132 \\
141\end{array}$ & $\begin{array}{l}28 \\
27 \\
15 \\
34 \\
38 \\
44 \\
47\end{array}$ & $\begin{array}{r}380 \\
368 \\
520 \\
650 \\
1140 \\
1120 \\
1008\end{array}$ & $\begin{array}{r}361 \\
351 \\
501 \\
611 \\
1013 \\
1097 \\
1069\end{array}$ & $\begin{array}{l}245 \\
252 \\
433 \\
480 \\
656 \\
826 \\
852\end{array}$ & $\begin{array}{r}87 \\
88 \\
89 \\
110 \\
347 \\
1190 \\
1201\end{array}$ \\
\hline
\end{tabular}

$E=$ enzymatic activity $\left(\mathrm{O}, \mathrm{D} . \times 10^{3}\right) ; \mathrm{I}_{\mathrm{t}}=$ trypsin inhibition $; \mathrm{I}_{\mathrm{c}}=$ chymotrypsin inhibition; $N=$ non-pregnant; $P_{3}$ to $20=3$ rd to 20 th day of pregnancy.

$0.025)$, from the 8 th to the 11 th day the activity again doubled $(P<0.025)$ and about the 20th day it reached a maximum just before delivery. Trypsin inhibitor activities also showed progressive increases, but on the 5th day there was a decrease in activity followed by further increases to the 18th day of gestation when maximal activity was reached.

The activity of GP-NA-ase was less than BA-NA-ase and chymotrypsin inhibitor levels were also less than those observed for trypsin inhibitor; in other respects progressive changes in these activities were analogous.

A comparison of the peptidases L-NA-ase, A-NA-ase, G-NA-ase and cy-NA-ase indicated that in non-pregnant uteri L-NA-ase was the highest while cy-NA-ase showed relatively low activity. Each enzyme progressively increased in activity from the early stages of gestation to about the 1lth day when the increase became very pronounced. By the 18th day maximal activity was reached for L-NA-ase and A-NA-ase; each was more than three times that of the non-pregnant 
uterus; G-NA-ase activity at this stage was three and a half times that of the non-pregnant uterus but cy-NA-ase activity continued to increase until the 20th day of gestation when it had attained more than thirteen times that of the nonpregnant uterus.

From the 11 th day of gestation onward the embryos were separated from their respective uteri and placentas and studied as well. These data are presented in Table 2. BA-NA-ase initially showed very little activity but increased steadily to reach peak activity on the 18th day of gestation; thereafter the activity decreased. Trypsin inhibitor also showed progressive increases which levelled off about the 18th day but there was no subsequent decrease in activity. L-NA-ase and A-NA-ase were the most active of the peptidases, each reaching its peak activity on the 20th day, while G-NA-ase reached maximum activity on the 18th day and cy-NA-ase continued to increase to the end of gestation. Unlike its activity in the uterus, embryonal cy-NA-ase was at no stage as high as L-NA-ase or G-NA-ase; L-NA-ase, unlike the other peptidases, showed a decrease in activity at the end of gestation.

TABLE 2

BIOCHEMICAL DATA OF PROTEOLYTIC ENZYME SYSTEMS IN RAT EMBRYOS AT VARIOUS STAGES OF DEVELOPMENT

\begin{tabular}{c|cc|c|c|c|c}
\hline \multirow{4}{*}{ Day } & \multicolumn{6}{|c}{ Substrate } \\
\cline { 2 - 7 } & \multicolumn{2}{|c|}{$B A-\mathcal{N} A$} & $L-\mathcal{N} A$ & $A-\mathcal{N} A$ & $G-\mathcal{N} A$ & $C y-\mathcal{N} A$ \\
\cline { 2 - 7 } & $E$ & $\% I_{\mathrm{t}}$ & $E$ & $E$ & $E$ & $E$ \\
\hline 11 & 45 & 15 & 212 & 197 & 87 & 49 \\
12 & 110 & 25 & 318 & 301 & 117 & 58 \\
14 & 210 & 33 & 442 & 397 & 214 & 104 \\
18 & 310 & 41 & 630 & 589 & 304 & 114 \\
20 & 150 & 43 & 840 & 805 & 298 & 153 \\
21 & 135 & 38 & 320 & 643 & 302 & 214 \\
\hline
\end{tabular}

$E=$ enzymatic activity $\left(\right.$ O.D. $\left.\times 10^{3}\right) ; I_{\mathbf{t}}=$ trypsin inhibition.

Text-fig. 1 summarizes the values obtained for BA-NA-ase and GP-NA-ase activities, as well as trypsin and chymotrypsin inhibitor levels of kidney, liver and spleen from the 18th day of gestation to 28 days post-natally. BA-NA-ase activity in foetal kidney, liver and spleen showed relatively low activity on the 18th day of gestation; activity increased on the 19th day, but then decreased to a low point on the 1st day post partum. In all three organs after the 2 nd day post partum the activity steadily increased and in the case of kidney and spleen it reached its maximum level on Day 14, while in liver the highest activity was on Day 28 post partum. Kidney initially did not have the highest BA-NA-ase activity but the rate of increase was greater than in the other tissues tested, as was the rate of decrease at birth. At its highest level (14 days) kidney showed more than nine times its minimum activity on Day $1(P<0.001)$; liver was six times more active on Day 28 than on Day $1(P<0.001)$, and spleen was twice as active on 
Day 14 as on Day $1(P<0.02)$. The corresponding trypsin inhibitor, in each tissue, from an initial low activity on Day 18 of gestation, prenatally, showed steady increases; liver and spleen attained highest activities on Day 14 while kidney inhibitor activity continued to increase up to Day 28. At that time, liver showed the highest activity and kidney had the lowest. The other endopeptidase, GP-NA-ase, was only studied in liver and kidney. This enzyme, though not

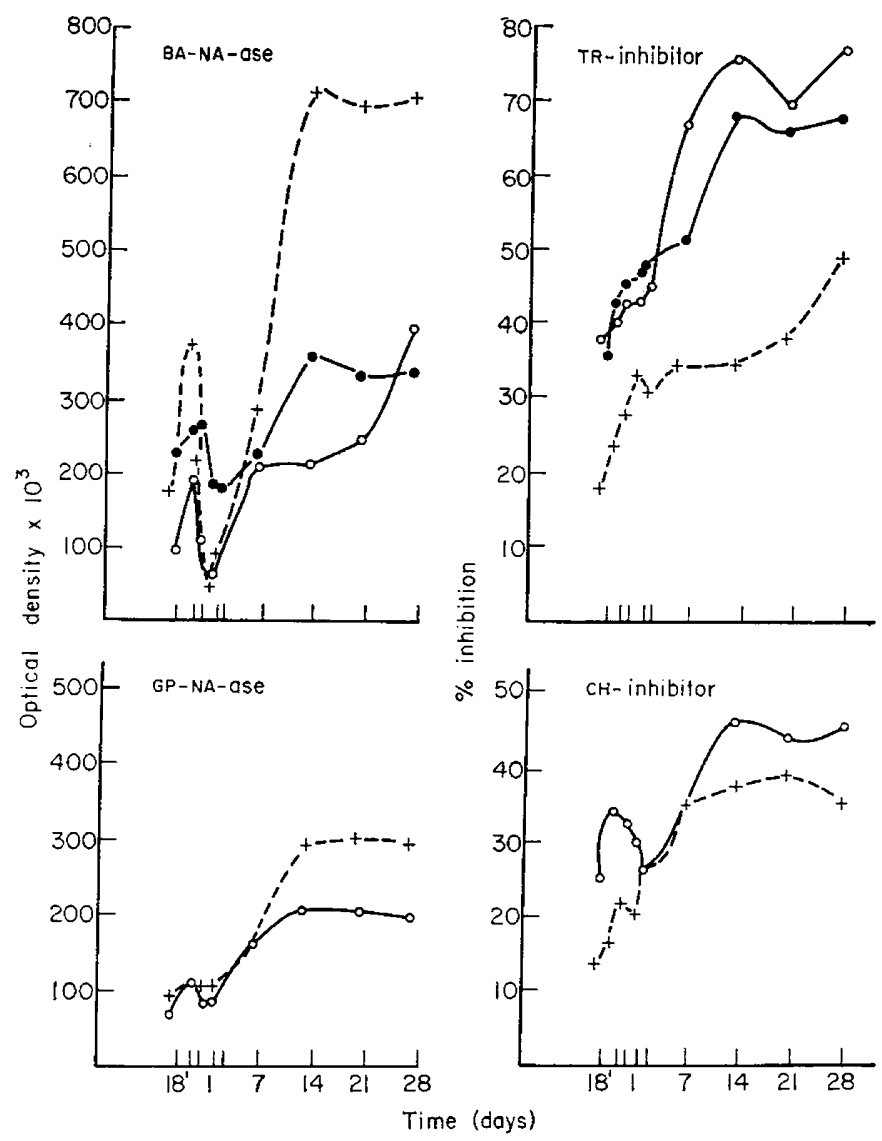

TEXT-FIG. 1. BA-NA-ase and GP-NA-ase activities and trypsin and chymotrypsin inhibitor levels in developing rat kidney $(+)$, liver $(0)$ and spleen $(\bullet)$.

as active as BA-NA-ase, showed similar changes in activity, i.e. low initial activity which increased, then decreased immediately following birth and increased again to reach the level of activity found in normal adult tissues about Day 14. Kidney had greater GP-NA-ase activity than liver. Chymotrypsin inhibitor levels were lower than trypsin inhibitor levels in both liver and kidney. As in the case of trypsin inhibitor, liver homogenates were more inhibitory than kidney homogenates.

BA-NA-ase and GP-NA-ase and the corresponding trypsin and chymotrypsin inhibitors are distinct entities. This is borne out by partial separation using differential ultracentrifugation procedures (Blackwood \& Mandl, 1964). 
Highest BA-NA-ase activity was found in the supernatant after centrifugation for $3 \mathrm{hr}$ at $90,000 \mathrm{~g}$ and the precipitate from the same centrifugation showed the highest trypsin inhibitor level. The highest GP-NA-ase activity was in the precipitate obtained on centrifugation at $90,000 \mathrm{~g}$ for $15 \mathrm{hr}$ and the highest

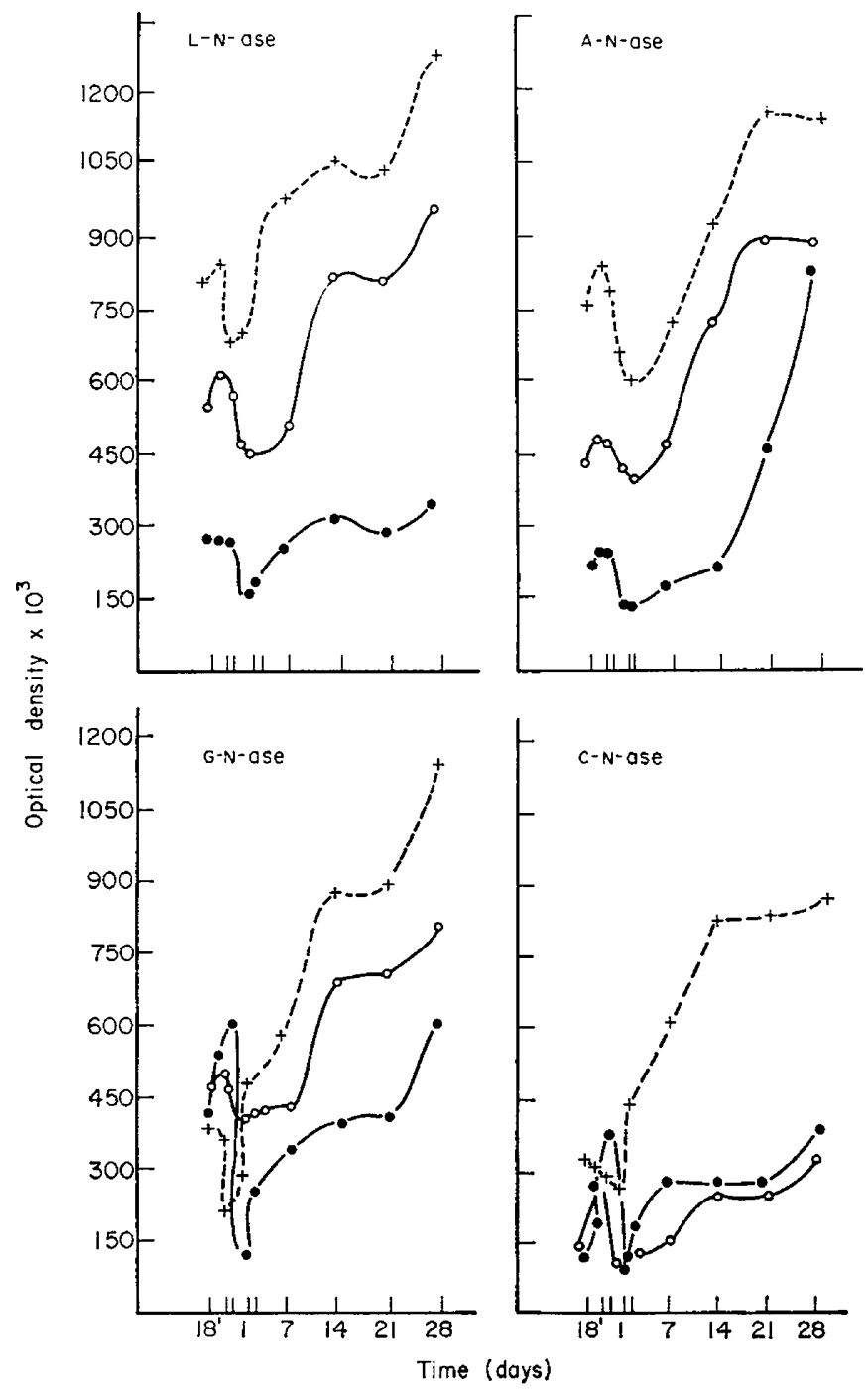

Texr-Fic. 2. L-NA-ase, A-NA-ase, G-NA-ase and cy-NA-ase activities in developing rat kidney $(t)$, liver $(0)$ and spleen $(0)$.

chymotrypsin inhibitor level was in a fraction layered just above the precipitate. Both inhibitors are non-dialysable and heat-stable compounds. Precipitates with higher inhibitor activity heated to $80^{\circ} \mathrm{G}$ for $30 \mathrm{~min}$ completely lost all proteolytic activity but still inhibited trypsin and chymotrypsin as well as the cathepsins. 
Text-fig. 2 summarizes observed changes in the activities of four peptidases in developing liver, kidney and spleen. In all three tissues L-NA-ase was most active, A-NA-ase, G-NA-ase and finally Cy-NA-ase showing successively less activity. Of the tissues studied, kidney showed the highest activity in all four peptidases. Each enzyme showed a sharp decrease in activity at birth followed by steady increases in activity to the adult level.

The results discussed so far refer to the total activities of each enzyme tested, both the soluble enzyme moieties and the particle-bound enzymes (Felgenhauer \& Glenner, 1965). These activities can be separated to a considerable extent by centrifugation in a Spinco L-2 ultracentrifuge. Data from a typical run are summarized in Table $3 . \mathrm{S}_{20}$ is the supernatant fraction of a 28-day-old kidney homogenate centrifuged at 20,000 $\mathrm{g}$ for $1 \mathrm{hr}, \mathrm{S}_{90}$ and $\mathrm{P}_{90}$ are the supernatant and precipitate fractions obtained after centrifugation of the $S_{20}$ fraction at $90,000 \mathrm{~g}$ for $15 \mathrm{hr}$, and $\mathrm{I}$ is an interphase fraction layered over the $\mathrm{P}_{\mathbf{9 0}}$ precipitate. All four ultracentrifuge fractions were tested against L-NA, A-NA, G-NA, Cy-NA and BA-NA to determine their proteolytic activities. $\mathrm{S}_{20}$ showed relatively high activities against each substrate corresponding to the sum of soluble and

TABLE 3

PROTEOLYTIC ACTIVITIES IN RAT KIDNEY FRACTIONS

\begin{tabular}{l|rrrr}
\hline \multirow{2}{*}{ Substrate } & \multicolumn{4}{|c}{ O.D. $\times 10^{\mathbf{3}}$} \\
\cline { 2 - 5 } & $S_{20}$ & \multicolumn{1}{|c}{$S_{90}$} & $I$ & $P_{90}$ \\
\hline L-NA & 760 & 75 & 820 & 840 \\
A-NA & 630 & 50 & 770 & 620 \\
G-NA & 350 & 45 & 600 & 560 \\
CY-NA & 210 & 450 & 530 & 210 \\
BA-NA & 580 & 760 & 820 & 90 \\
\hline
\end{tabular}

particle-bound enzymes. In $\mathrm{S}_{90}$ only soluble enzymes were assayed, whereas in I and $P_{90}$ the particle-bound enzymes were assayed. Comparison of the activities found in $\mathrm{S}_{90}$ with those in I or $\mathrm{P}_{90}$ showed that the ratio of soluble enzyme to particulate was $1: 11$ in the case of L-NA-ase, and more than $1: 12$ for $\mathrm{A}-\mathrm{NA}$-ase and G-NA-ase. On the other hand, the same ratio was 2:1 for cy-NA-ase and 8:1 for BA-NA-ase. These results indicate that the enzymes hydrolysing the substrates L-NA, G-NA and A-NA occur largely as particulate enzymes while those hydrolysing Cy-NA and BA-NA are present mostly in the soluble form. The histochemical assays discussed below apply only to sites of particulate enzyme activity.

Metal ion and -SH group dependence of both endopeptidases and exopeptidases in the various ultracentrifuge fractions were evaluated. The $S_{20}$ fraction of kidney was activated by $\mathrm{CoCl}_{2}$ against each peptidase substrate. The $\mathrm{S}_{90}$ fraction was activated against L-NA and A-NA but not affected against CY-NA or G-NA. P $_{90}$ was not affected against L-NA; however, against G-NA and A-NA it was activated and against Cy-NA it was inhibited. Neither metal ions nor -SH groups had any effect on BA-NA-ase activity in the complete system but 
PI.ATE 1

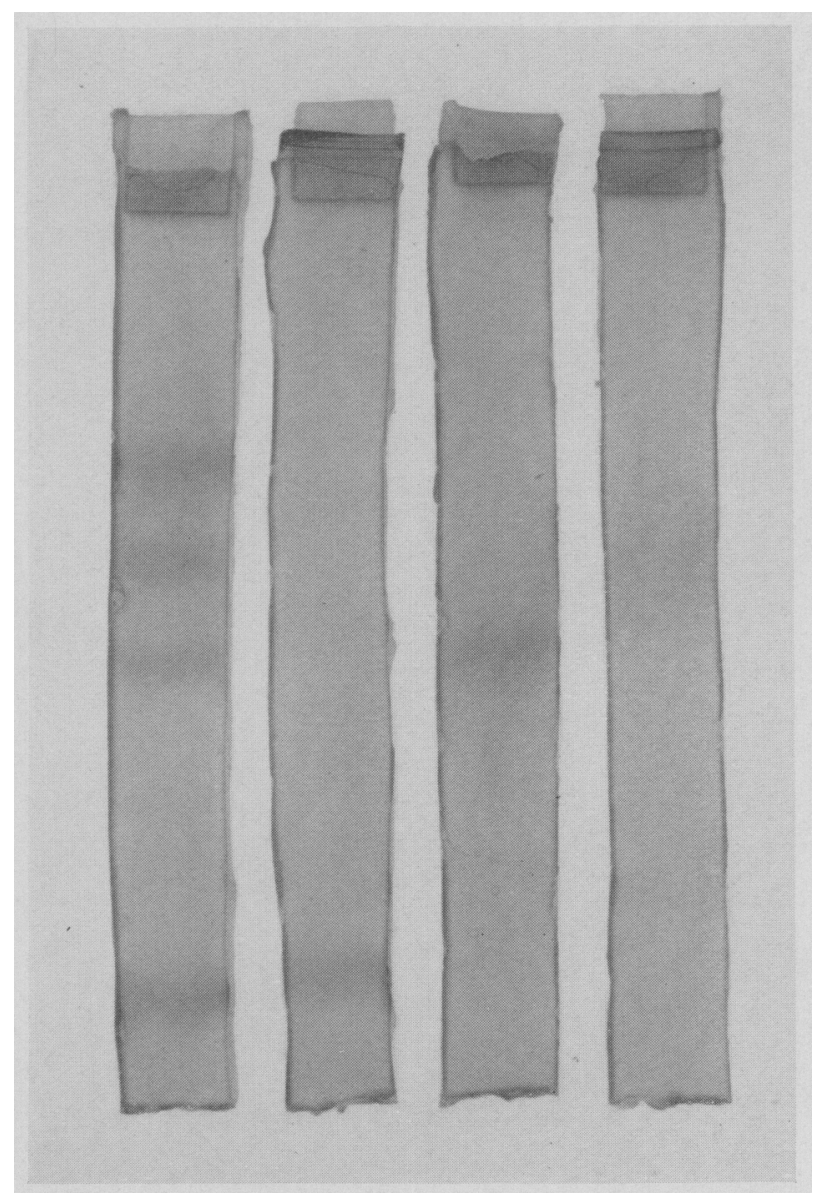

FIG. 1. Acrylamide gel electrophoretograms showing mobilities of four peptidases in adult rat kidney. Left to right: L-NA-ase, A-NA-ase, G-NA-ase and Cy-NA-ase. 
PIATE 2

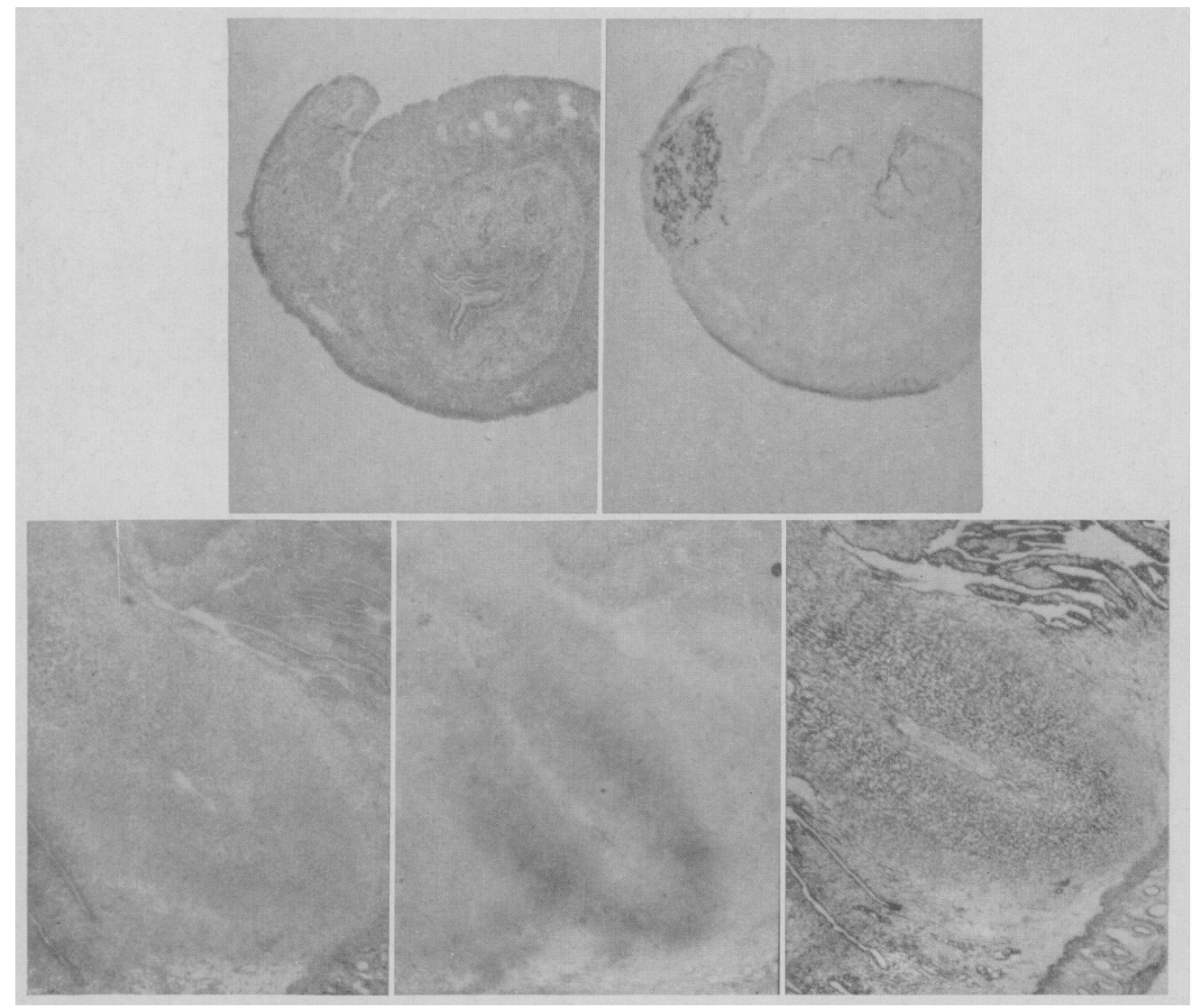

FIG. 2. Top: cross-sections of $\bar{j}$-day-old pregnant rat uterus. Left: stained with H \& E; right: rcacted against L-NA. Bottom: cross-sections of 8-day-old embryos. Left: stained with $\mathrm{H} \& \mathrm{E}$; centre: sites of L-NA-ase activity; right: sites of succinic dehydrogenase activity. $\times 20$

(Facing p. 27) 
after dialysis it was activated by cysteine; GP-NA-ase, on the other hand, was not affected by -SH compounds. Cysteine inhibited L-NA-ase, A-NA-ase and G-NA-ase but it activated cy-NA-ase.

Plate 1, Fig. 1 illustrates the electrophoretic mobilities of the four peptidases studied. The electrophoretogram shown was obtained by preparative acrylamide gel electrophoresis of a kidney $S_{20}$ fraction. The gel strip on the left was incubated in L-NA for 3 hours and then stained with Fast Garnet GBC, the others were incubated for the same time in A-NA, G-NA and cy-NA, respectively, and stained. The gel strip incubated in L-NA showed four bands, the others one each. The enzyme hydrolysing A-NA had the same electrophoretic mobility as the fourth L-NA-ase band, the band obtained with G-NA as substrate corresponded to the third L-NA-ase band. The Gy-NA-ase band was weaker and diffuse and located between the second and third L-NA-ase bands.

\section{Histochemical studies}

Table 4 compares relative peptidase activities in a histochemical system in $8 \mu$ cryostat cut sections of kidney, liver and spleen, at different stages of development from Day 1 to Day 21. The time in minutes of the first appearance of

TABLE 4

HISTOCHEMICAL QUANTITATION OF PEPTIDASES IN DEVELOPING KIDNEY, LIVER AND SPLEEN

\begin{tabular}{|c|c|c|c|c|c|c|c|c|c|c|c|c|}
\hline \multirow{3}{*}{ Substrate } & \multicolumn{4}{|c|}{ Kidney } & \multicolumn{4}{|c|}{ Liver } & \multicolumn{4}{|c|}{ Spleen } \\
\hline & \multicolumn{2}{|c|}{ Appearance } & \multicolumn{2}{|c|}{ Activity } & \multicolumn{2}{|c|}{ Appearance } & \multicolumn{2}{|c|}{ Activity } & \multicolumn{2}{|c|}{ Appearance } & \multicolumn{2}{|c|}{ Activity } \\
\hline & Min. & Day & 1 Day & 4 Day & Min. & Day & 1 Day & $4 D a y$ & Min. & Day & 1 Day & 4 Day \\
\hline $\begin{array}{l}\text { L-NA } \\
\text { A-NA } \\
\text { G-NA } \\
\text { CY-NA }\end{array}$ & $\begin{array}{r}2 \\
3 \\
2 \\
15\end{array}$ & $\begin{array}{c}1 \\
1 \\
1 \\
21( \pm)\end{array}$ & $\begin{array}{l}+t \\
++ \\
++ \\
-\end{array}$ & $\begin{array}{c}+++ \\
++(+) \\
+++ \\
+\end{array}$ & $\begin{array}{r}4 \\
6 \\
5 \\
25\end{array}$ & $\begin{array}{c}1 \\
1 \\
1 \\
21( \pm)\end{array}$ & $\begin{array}{l}+ \\
\pm \\
\pm \\
+\end{array}$ & $\begin{array}{l}+ \\
+ \\
\pm \\
\pm\end{array}$ & $\begin{array}{r}5 \\
7 \\
6 \\
36\end{array}$ & $\begin{array}{c}1 \\
8 \\
8 \\
21( \pm)\end{array}$ & $\begin{array}{l} \pm \\
\pm \\
\pm\end{array}$ & $\begin{array}{l} \pm \\
\pm \\
-\end{array}$ \\
\hline
\end{tabular}

Min. = time in minutes at which colour reaction first appears; Day $=$ first day on which colour reaction can be observed; 1 Day, 4 Day $=$ relative activity on Days 1 and 4 .

colour was measured and the subjective quantitation of colour intensity after $1 \frac{1}{2} \mathrm{hr}$ incubation was determined. A-NA-ase colour appeared later than L-NA-ase or G-NA-ase in kidney and liver and could not be detected at all in spleen until the 8th day; G-NA-ase was also lacking in 4-day-old spleen and no cy-NA-ase activity appeared in any of the 1-day- or 4-day-old tissues. Colour intensity was approximately equal against L-NA, G-NA and A-NA in kidney, +++ ; in 4-dayold liver all activities were less and activity observable against G-NA was very low. Comparisons of enzyme activities in the tissues of litter mates starting within the first $24 \mathrm{hr}$ post partum did not reveal any apparent increases (during the first 7 days). On about Day 8 activities of kidney L-NA-ase, A-NA-ase and G-NA-ase increased to +++ but the time of first appearance of colour remained unchanged. Similar increases in activity were also observed in liver, from + to ++ for L-NA-ase, A-NA-ase and G-NA-ase. Not until the 8 th day did A-NA-ase and G-NA-ase appear in spleen, with very little activity in the case of A-NA-ase, more in 
the case of G-NA-ase; the time of first appearance of colour was 4 min for both substrates. Cy-NA-ase did not appear until the 21 st day in any tissue. This activity was low in all cases and the time of initial appearance of colour was 15, 21 and $36 \mathrm{~min}$, respectively, for kidney, liver and spleen.

Plate 2, Fig. 2, top, represents cross-sections of a 5-day-old pregnant uterus. On the left is a haematoxylin and eosin section and next to it an L-NA reacted section. This localizes enzyme activity near the mesometrial pole of the embryo. This enzyme disappeared shortly after the 5th day of gestation. Plate 2, Fig. 2, bottom, shows cross-sections of 8-day-old embryos, haematoxylin and eosin stained and reacted for $\mathrm{L}$-NA-ase and succinic dehydrogenase. Both activities are localized in the extra-embryonic membranes of the embryo.

Plate 3, Fig. 3 is a histochemical demonstration of L-NA-ase (on the top part of the plate) in 28-day-old kidney, liver and spleen compared to 4-day-old kidney, liver and spleen (in the bottom part). In the mature kidney the highest activity was located in areas surrounding the medulla while in the 4-day-old kidney it was evenly distributed throughout the developing tissue. Relatively little activity was seen in mature liver and spleen tissues. The activity in liver was located around blood vessels. In 4-day-old liver and spleen only little activity could be demonstrated. The observable increase in enzyme activity with age is demonstrated in Pl. 3, Fig. 4. L-NA-ase (top) and A-NA-ase (bottom) are reacted with 1-, 4- and 21-day-old kidney tissues. The plate demonstrates the growth of kidney tissue and the increase of enzyme activities with age.

The sites of activity against both substrates were indistinguishable. Against G-NA the site of activity was, however, distinct. Plate 4, Fig. 5 demonstrates that this activity was highest in the glomeruli (top right), while L-NA-ase showed no activity at that site. Localization in liver (bottom of Pl. 4, Fig. 5) appeared the same for both substrates though there was more L-NA-ase than G-NA-ase. The effect of metal ions on these peptidases was evaluated in kidney tissue. Plate 4, Fig. 6 bottom, shows kidney tissue reacted against cy-NA (left), L-NA (centre) and G-NA (right); in the top part $\mathrm{CoCl}_{2}$ was added to the system and found to activate G-NA-ase, to be without effect on L-NA-ase and to inhibit Cy-NA-ase. A-NA-ase (not shown) like $\mathrm{L}$-NA-ase was not affected by $\mathrm{CoCl}_{2}$.

\section{DISCUSSION}

The results reported show that even in the earliest stages of embryonic development complexes between proteolytic enzymes and their inhibitors have been formed. It appears that several closely related but distinct inhibitors can take part in such systems and that differences exist between analogous systems in various organs. Both enzyme and inhibitor activities increase as development proceeds. In all probability the specific function of the enzymes is determined by the physiological requirements of the tissues as they grow and differentiate.

FIG. 3. Sites of L-NA-ase activity. Top (left to right) in 28-day-old kidney, liver and spleen. Bottom (left to right) in 4-day-old kidney, liver and spleen. $\times 80$.

FIG. 4. L-NA-ase activity (top) and A-NA-ase activity (bottom) in (left to right) 1-, 4- and 21-day-old kidney tissues. $\times 80$. 
PIATE 3

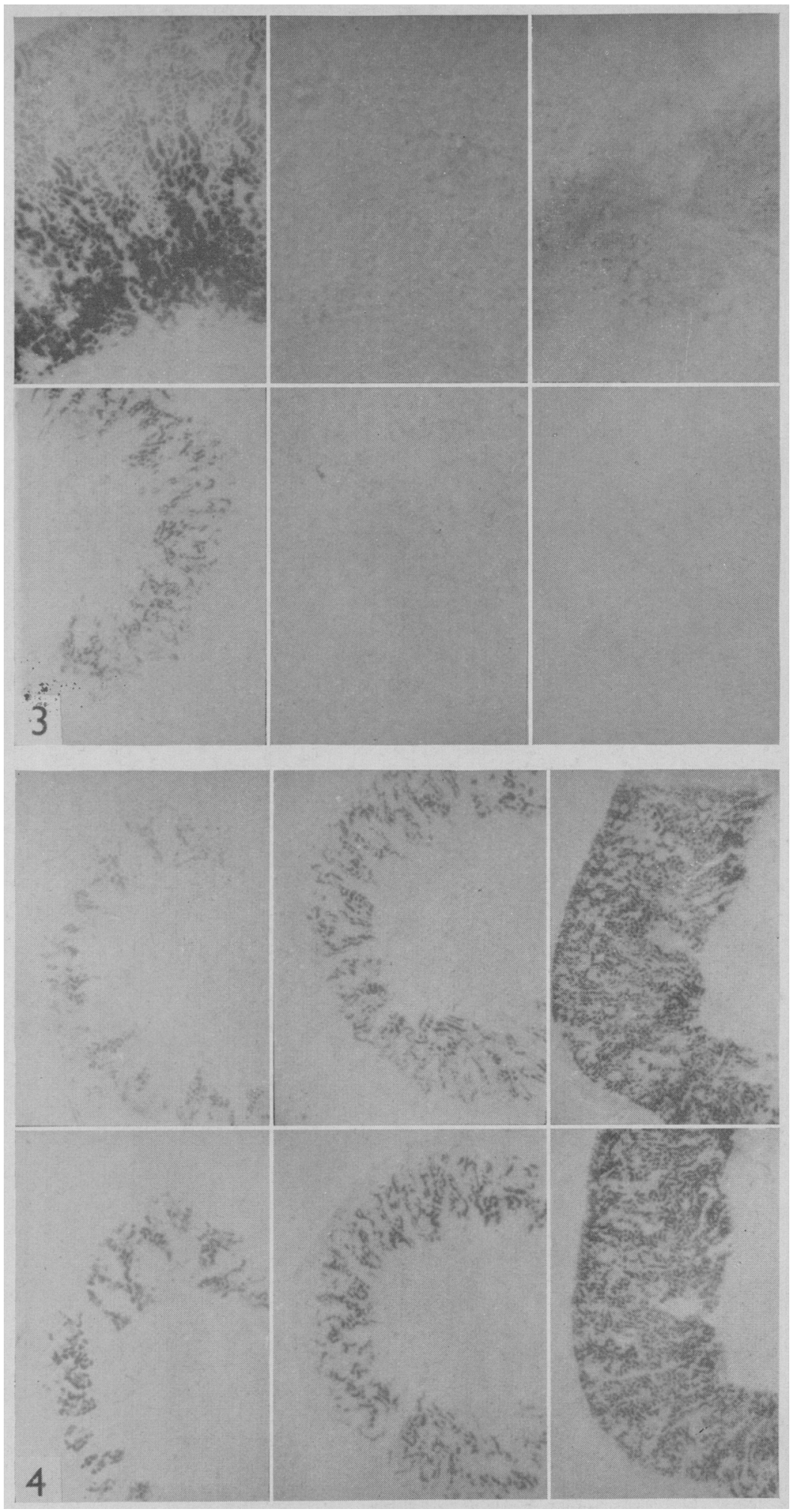


PLATE 4
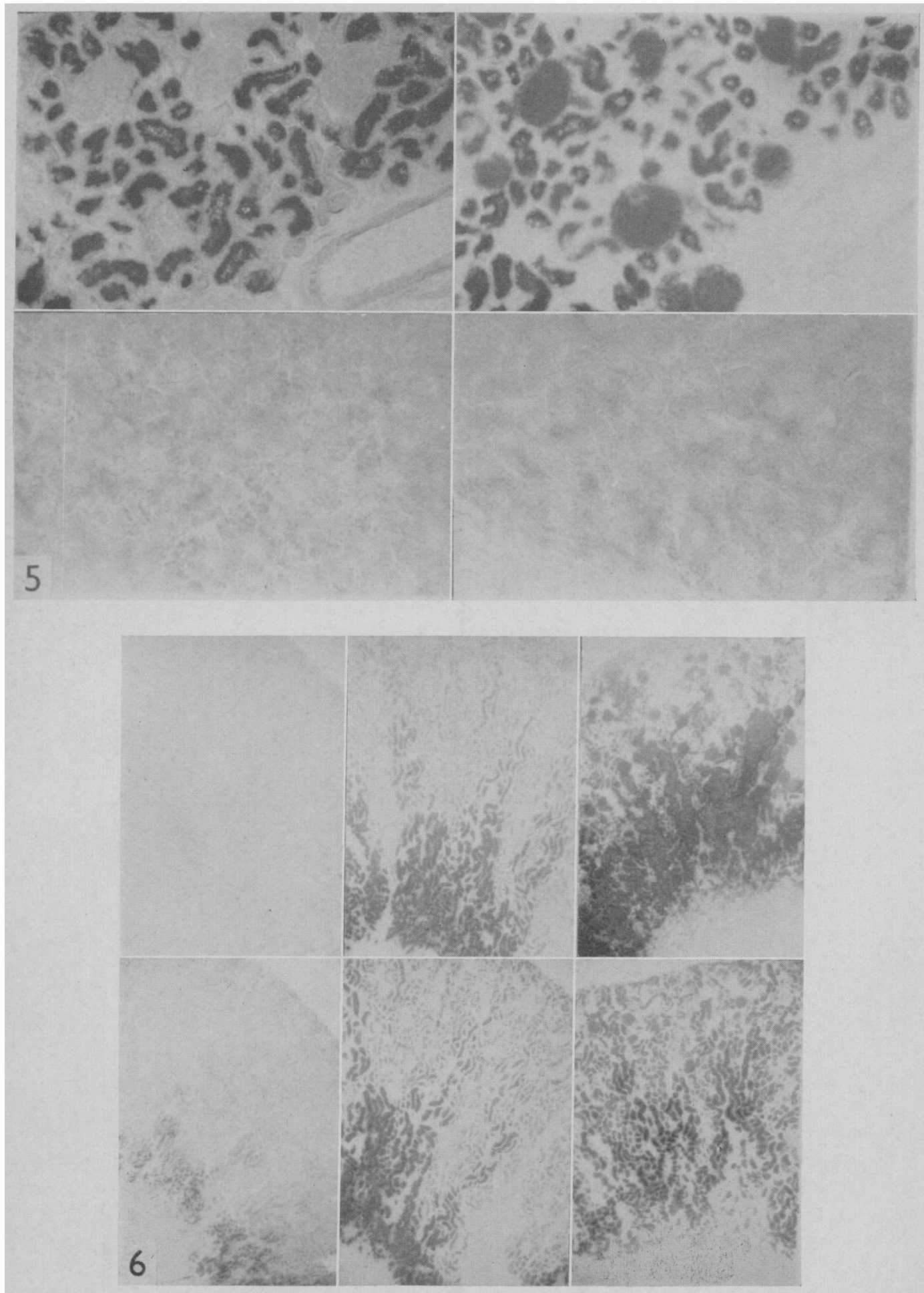

(Facing p. 29) 
Growth and development are gene controlled and so is the evolution of enzyme systems. The rate of release of enzymes from their complexes to mediate the degradation of proteins and peptides would then depend on the amino acid pool from which the developing embryo must draw the building blocks for synthesis of its specific proteins. The increased endopeptidase activity found on Day 5 of gestation is a reflection of the decreased inhibitor levels on that same day. Such a state is reminiscent of the relationship found in malignant tissues where increased proteolytic activity in the more malignant tissues was accompanied by decreased inhibitor levels (Blackwood et al., 1965b). Day 5 in the gestation period of the rat is the approximate time of nidation of the trophoblast in the uterus and it seems reasonable to assume that the changes in enzyme activity observed on that day may have some connection with the nidation process. Higher enzyme levels may be required to dissolve surrounding tissues and anchor the trophoblast or form a nutritive matrix for the early development of the embryo. Since, during the course of development, endopeptidases as well as their inhibitors increase in activity, the enzyme activities assayed are a measure of the available enzyme in the system and not the total enzyme concentration. From the values obtained for the available enzyme activity and the inhibitor present the total enzyme concentration can be calculated. On that basis BA-NA-ase activity in the 20-day pregnant uterus shows a more than thirty-fold increase over non-pregnant uterus.

The enzymes assayed in biochemical systems are not necessarily the same as those localized in histochemical systems. Felgenhauer \& Glenner (1965) pointed out that the primary concern of the histochemist is the study of enzymes that are present in tissues in an insoluble state or can be made insoluble by denaturing techniques, i.e. the localization of particulate enzymes. The biochemist, on the other hand, studies soluble enzymes or particulate enzymes made soluble. If peptidases are membrane enzymes, as suggested by Felgenhauer \& Glenner (1966), the membranes are disrupted by the homogenization preceding biochemical studies, whereas in histochemical systems the requisite substrate penetration into intact tissue may only be possible to a limited extent. The high BA-NA-ase activities in the soluble fractions and the concomitant low activities in the particulate fractions indicate that histochemically BA-NA-ase is difficult to identify, and explain the failure to find sites of activity in pre-natal or postnatal tissues. The same reasoning applies also to Cy-NA-ase. This enzyme was found to be present in prenatal tissues by biochemical methods of analysis but histochemical methods gave negative results up to Day 21 when cy-NA-ase was first localized in post-natal tissues. Ultracentrifugation at $90,000 \mathrm{~g}$ separates homogenates previously subjected to $20,000 \mathrm{~g}$ into two fractions, apparently equivalent to the soluble and the particulate enzymes. The precipitate obtained from the $20,000 \mathrm{~g}$ supernate, $P_{90}$, corresponds to the particulate enzyme localized by the histochemical procedures. This is borne out by comparison of the effect of

\section{EXPLANATION OF PLATE 4}

FIG. 5. L-NA-ase activity (left) and G-NA-ase activity (right) in 28-day-old kidney (top) and liver (bottom). $\times 320$.

Frg. 6. Adult kidney tissue reacted against (left to right) Cy-NA, L-NA and G-NA. Top: reacted in the presence of $10^{-2} \mathrm{M}_{-}-\mathrm{CoCI}_{2}$. Bottom: no metal added. $\times 80$. 
metal ions on the different fractions. When $\mathrm{CoCl}_{2}$ was added to $\mathbf{P}_{90}$ in the biochemical assay system, the same pattern of metal activation or inhibition was obtained as in the histochemical system, but $\mathrm{S}_{90}$ was affected in a different way. High activities in a biochemical assay system do not always coincide with high levels in the histochemical demonstration of the enzymes. In 7-day-old liver and spleen, activities against A-NA and G-NA appeared higher than in 1-day-old kidney when assayed by biochemical procedures. In the histochemical system, however, there was higher activity in 1-day-old kidney than in 7-day-old liver and spleen, indicating that the two systems did not assay the identical enzymes.

Time of first appearance of the reaction product is a good indication of the relative amounts of the enzyme localized, as shown for L-NA-ase by Long \& Hosannah (1966). The correlation between rate of colour development and quantitative evaluation had previously been demonstrated by Hopsu \& Glenner (1963), and confirmed by Engel, Eyerman \& Williams (1963). We have applied this concept to confirm differences in the activities of peptidases in developing kidney, liver and spleen. One-day-post partum kidney had the same relative activities for L-NA-ase, A-NA-ase and G-NA-ase on the basis of histochemically localized sites of activity; in the biochemical system, however, L-NAase was more than twice as active as G-NA-ase or Cy-NA-ase though A-NA-ase still showed the same level of activity as L-NA-ase. In liver, kidney and spleen on Day 18 of gestation the biochemical activities appeared higher than on Day 1 post partum; histochemically, however, 1-day-old tissues showed more activity than prenatal tissues. Since in 21-day-old kidney Cy-NA-ase showed greater activity biochemically than L-NA-ase in 1-day-old tissue while L-NA-ase in 1day-old kidney histochemically appeared more active than cy-NA-ase at 21 days, the conclusion appears valid that soluble enzymes are synthesized before particulate enzymes.

In the 10-day-old developing embryo, high peptidase activity was observed in the extra-embryonal area and in placental tissues, while in the embryo proper only low activity was observed. At this stage of development there is a rapid migration and proliferation of cells. High levels of succinic dehydrogenase (a high energy producing enzyme) were observed at the same site as the peptidase activity. This may indicate that the high peptidase activity is associated with the breakdown of macromolecules to supply the needs of the highly proliferative activities in the embryonal area. When high proteolytic activity is not associated with energy producing enzymes, the proteolytic enzymes are probably concerned with tissue degeneration as in necrotic tissue.

The relative activities in non-pregnant uterus against the substrates L-NA and cy-NA were in the ratio of $4: 1$. Both these activities increased as pregnancy progressed, but the increase was more pronounced in the case of cy-NA-ase. The rapid rise in Cy-NA-ase activity may be associated with oxytocinase production. Tuppy \& Nesvadba (1957) have used cy-NA as a substrate for serum oxytocinase and several investigators (Fylling, 1963; Ichaliotis \& Lambrinopoulos, 1965; Melander, 1965) have demonstrated similarities suggesting possible identity between cy-NA-ase and oxytocinase activity. Ryden (1966) in a recent study of oxytocinase in human and rat placenta using cy-NA as substrate, observed that the high plasma oxytocinase activity characteristic of human pregnancy 
had its origin in the placenta as its primary site. Our results corroborate these findings. The physiological significance of this enzyme in pregnancy is unknown; as suggested by Ryden (1966) it might act as a protection against the increased activity of renin-angiotensin associated with pregnancy.

Table 5 illustrates the relationship between BA-NA-ase, L-NA-ase, G-NA-ase and cy-NA-ase in developing tissues. A unit value of one was arbitrarily assigned to the lowest activity in each series and all others rated correspondingly. Foetal kidney, liver and spleen, as well as non-pregnant uterus, gave characteristic patterns of relative enzyme activities. While in foetal liver BA-NA-ase and CyNA-ase showed a 1:1 ratio of activity, the relative activity of G-NA-ase was twice as high and that of L-NA-ase three times more; in kidney BA-NA-ase, G-NA-ase and Cy-NA-ase showed similar relative activity and L-NA-ase was twice as high, and in spleen L-NA-ase was as low as Cy-NA-ase, while BA-NA-ase and G-NA-ase both showed twice as much relative activity. In non-pregnant uterus the ratio of BA-NA-ase to Cy-NA-ase was 2:1 and both L-NA-ase and G-NA-ase"showed two

TABLE 5

PATTERN OF RELATIVE PROTEOLYTIC ENZYME ACTIVITIES IN RAT TISSUES

\begin{tabular}{|c|c|c|c|c|}
\hline & $B A-\mathcal{N} A$-ase & $L$-NA-ase & $G$-NA-ase & $C y-\mathcal{N} A$-ase \\
\hline $\begin{array}{l}\text { Liver } \\
\text { Foetal } \\
\text { Adult }\end{array}$ & $\begin{array}{l}1 \\
3\end{array}$ & $\begin{array}{l}3 \\
3\end{array}$ & $\begin{array}{l}2 \\
3\end{array}$ & $\begin{array}{l}1 \\
1\end{array}$ \\
\hline $\begin{array}{l}\text { Kidney } \\
\text { Foetal } \\
\text { Adult }\end{array}$ & $\begin{array}{l}1 \\
2\end{array}$ & $\frac{2}{2}$ & $\begin{array}{l}1 \\
2\end{array}$ & $\begin{array}{l}1 \\
1\end{array}$ \\
\hline $\begin{array}{l}\text { Spleen } \\
\text { Foetal } \\
\text { Adult }\end{array}$ & $\begin{array}{l}2 \\
4\end{array}$ & 1 & $\begin{array}{l}2 \\
2\end{array}$ & $\begin{array}{l}1 \\
1\end{array}$ \\
\hline $\begin{array}{l}\text { Uterus } \\
\text { Non-pregnant } \\
\text { Pregnant }\end{array}$ & $\begin{array}{l}1 \\
3\end{array}$ & $\begin{array}{l}2 \\
1\end{array}$ & $\begin{array}{l}2 \\
1\end{array}$ & $\begin{array}{l}0.5 \\
1\end{array}$ \\
\hline
\end{tabular}

Foetal $=20$ th day of gestation; Adult $=28$ days post-natal.

times more relative activity than BA-NA-ase. The most significant change from foetal to adult tissues was in the BA-NA-ase levels. In each adult tissue examined BA-NA-ase increased more than the other enzymes, the change in ratio being more pronounced in liver and uterus than in kidney and spleen. The relative amount of Gy-NA-ase did not change with development in liver, kidney and spleen but there was considerable difference between pregnant and non-pregnant uterus. The ratio of Cy-NA-ase to L-NA-ase in non-pregnant uterus was $1: 4$ and in the pregnant uterus this ratio became $1: 1$. Similarly L-NA-ase retained its relative activity throughout development in liver, kidney and spleen. Relative L-NA-ase activity in the pregnant uterus was less than the activity in the non-pregnant uterus. A basic characteristic of each tissue is its specific enzyme pattern. It appears to change as development progresses to accommodate the requirements of the tissue.

A close relationship must exist between metabolic requirements and the 
development of proteolytic enzyme systems. The evaluation of differences in enzyme activities in immature and adult tissues may provide insight into the biochemistry of developing tissues. The biochemical mechanisms that control cellular differentiation are still incompletely understood. Christensen \& Streicher (1948) demonstrated that amino acid concentration in intracellular spaces is high when tissues grow rapidly. The presence of particle-bound enzymes demonstrated in histochemical systems at the brush border of hog renal proximal tubuli indicates cell membrane enzymes, which may in effect be contributory factors in the accumulation of these amino acids in intracellular spaces. The higher rate of incorporation of labelled amino acids into tissue proteins in early life, as found by Greenberg, Friedberg, Schulman \& Winnick (1948) in the brain and liver of chick embryo and by Zamecnick, Frantz, Loftfield \& Stephenson (1948) in rat liver, may explain the shift in enzyme patterns from foetal to adult tissues, from predominantly peptidase activity to larger amounts of proteinase activity, a shift which indicates that the breakdown of protein to peptides increases in importance compared to the breakdown of peptides to amino acids. The involvement of proteolytic enzymes as part of a system operating in the mechanism of cellular function has been documented in several studies. Mention may be made of evidence adduced by Means, De Groot \& Stanburg (1963) who showed the amino acid leucine and L-NA-ase in the epithelial cells of thyroids; Nadler et al. (1960) suggested that the enzyme is either a link in the synthesis of thyroglobin or involved in the release of thyroid hormone from its storage product. Pearse \& Tremblay (1958) found a close correlation between L-NA-ase activity in parathyroid glands and the rate of parathyroid production.

The decrease in proteolytic activity at birth may reflect a transition period marking the end of tissue differentiation and the gradual acquisition of full functionality with steady increase in enzyme activities. During the early stages of development there is an imbalance between synthesis and catabolism, with the former predominating over the latter. At all levels the system is controlled by enzyme inhibitors, so that catabolism is favoured where specific metabolites are needed and held in abeyance once the requirements are met.

\section{ACKNOWLEDGMENT}

This work was supported in part by United States Public Health Service Grant HD 03256.

\section{REFERENCES}

Anderson, N. G. (1955) Studies on isolated cell components. VIII. High resolution differential centrifugation. Expl Cell Res. 9, 446.

Blackwood, C., ErLANGer, B. F. \& Mandi, I. (1965a) A new test specific for the determination of chymotrypsin and cathepsin C. Analyt. Biochem. 12, 128.

Blackwood, G. \& Mande, I. (1961) An improved test for the determination of trypsin, trypsin-like enzymes and enzyme inhibitors. Analyt. Biochem. 2, 370 .

Blackwood, C. \& Mande, I. (1964) Proteolytic inhibitors in normal and tumor tissue. f. Cell Biol. 23, $11 \mathrm{~A}$.

Blackwood, C., Mandi, I. \& Long, M. E. (1965b) Proteolytic enzymes and their inhibitors in human gynecological tumors. Am. 7. Obstet. Gynec. $91,419$.

Btackwood, C. E., Mateyko, G. M. \& Mande, I. (1962) Changes in proteolytic enzyme systems of rat tissues in response to heterologous growth of human ovarian tumors. Cancer Res. 22, 993. 
Bratton, A. C. \& Marshall, E. K. (1939) A new coupling test for sulfanilamide determination. . biol. Chem. 128, 537.

Christensen, H. N. \& Streicher, J. A. (1948) Association between rapid growth and elevated cell concentration of amino acids. 7. biol. Chem. 125, 95.

Deuchar, E. M. (1960) The effect of an amino acid analog on catheptic activity in somite mesoderm of the chick embryo. Devel. Biol. 2, 129.

Engel, V. K., Eyerman, E. L. \& Williams, H. E. (1963) Late-onset type of skeletal-muscle phosphorylase deficiency. New Engl. F. Med. 268, 135.

Felgenhauer, K. \& Glenner, G. G. (1965) Quantitation of tissue-bound renal aminopeptidase by a microdensitometric technique. F. Histochem. Cytochem. 14, 53.

Felgenhauer, K. \& Glenner, G. G. (1966) The enzymatic hydrolysis of amino acid $\beta$-naphthylamides. II. Partial purification and properties of a particle-bound cobalt-activated rat kidney aminopeptidase. F. Histochem. Cytochem. 14, 401.

Fylling, P. (1963) Serum and plasma oxytocinase activity during induction of labor. Acta obstet. gynec. scand. 42, 227.

GlenNer, G. G. (1962) The preservation of peptidase activity localization using $\beta$-naphthylamide substrate. F. Histochem. Cytochem. 10, 257.

Greenberg, D. M., Friedberg, F., Schulman, M. P. \& Winnick, T. (1948) Studies on mechanism of protein synthesis with radioactive carbon-labeled compounds. Cold Spring Harb. Symp. quant. Biol. 13, 113.

Goldbarg, J. A., Pineda, E. P. \& Rutenburg, A. M. (1959) The measurement of activity of leucine aminopeptidase in serum, urine, bile and tissues. Am. F. clin. Path. 32, 571.

Hopsu, V. K. \& Glenner, G. G. (1963) A histochemical enzyme kinetic system applied to the trypsinlike amidase and esterase activity in human mast cells. F. Cell Biol. 17, 503.

Ichaliotis, S. D. \& Lambrinopoulos, Th. C. (1965) Serum oxytocinase in twin pregnancy. Obstet. Gynec., N.Y. 25, 270.

JosefsSon, L. \& LindBeRg, T. (1965) Intestinal dipeptidase. II. Distribution of dipeptidase activity in the small intestine of the pig. Biochim. biophys. Acta, 105, 162.

Lieberman, J. (1966) Proteolytic enzyme activity in fetal pancreas and meconium. Demonstration of plasminogen and trypsinogen activators in pancreatic tissue. Gastroenterology, 50, 183.

LiNDBeRg, T. (1966) Intestinal dipeptidases: Characterization, development and distribution of intestinal dipeptidases of the human foetus. Clin. Sci. 30, 505.

LindBerg, T. \& OWman, C. (1966) Intestinal dipeptidase activity in the small intestine of the rat as related to the development of the intestinal mucosa. Acta physiol. scand. 68, 141.

Long, M. E. \& Hosannah, Y. T. (1966) Comparative histochemical studies of L-leucyl- $\beta$-naphthylamidase in ovarian epithelial tumors. Cancer, N.Y. 19, 909.

MARKHAm, R. (1942) A steam distillation apparatus suitable for micro-Kjeldahl analysis. Biochem. $\mathcal{F}$. $36,790$.

Mayersbach, H. von (1958) Zur Frage des Proteinueberganges von der Mutter zum Foetus. I. Befunde an Ratten am Ende der Schwangerschaft. Z. Zellforsch. mikrosk. Anat. 48, 479.

Means, S. H., De Groot, L. J. \& Stanburg, S. B. (1963) The thyroid and its diseases, p. 43. The Blakiston Division, McGraw-Hill, New York.

Melander, S. E. J. (1965) Plasma oxytocinase activity. Acta endocr., Copenh. 48, Suppl. 96.

Nadler, N. J., LeBlond, G. P. \& Carneiro, J. (1960) Site of formation of thyroglobulin in mouse thyroid as shown by radioautography with leucine- $\mathrm{H}^{3}$. Proc. Soc. exp. Biol. Med. 105, 38.

Pearse, A. G. E. \& Tremblay, G. (1958) Leucine aminopeptidase in rat parathyroid and its relation to parathyroid hormone production. Nature, Lond. 181, 1532.

Raymond, S. (1962) A convenient apparatus for vertical gel electrophoresis. Clin. Chem. 8, 455.

Ryden, G. (1966) Cystine aminopeptidase and oxytocinase activity in pregnancy. Acta obstet. gynec. scand. 45, Suppl. $3,1$.

SAunders, J. W. (1966) Death in embryonic systems. Science, N.r. 154, 604.

Schneiderman, H. A. \& Gilbert, L. (1964) Control of growth and development in insects. Science, $\mathcal{N} . r$. $143,325$.

Tuppy, H. \& Nesvadba, H. (1957) Ueber die Aminopeptidaseaktivitaet des Schwangerenserums und ihre Beziehung zu dessen Vermoegen, Oxytocin zu inaktivieren. Mn. Chem. 88, 977.

WEBER, R. (1962) Induced metamorphosis in isolated tails of Xenopus larvae. Experientia, 18, 84.

WEISs, P. \& RossETTI, F. (1951) Growth responses of opposite sign among different neuron types exposed to thyroid hormone. Proc. natn. Acad. Sci. U.S.A. 37, 540.

Zamechik, P. C., Frantz, I. D., Loftfield, R. B. \& Stephenson, M. L. (1948) Incorporation in vitro of radioactive carbon from carboxyl labeled DL-alanine and glycine into proteins of normal and malignant rat liver. J. biol. Chem. 175, 299. 